\title{
Multiallergentest mit getrocknetem Blut
}

Mit Hilfe eines an der MedUni Wien mitentwickelten Allergie-Chips lassen sich frühzeitig allergische Sensibilisierungen erkennen. Dazu war bisher die Blutabnahme beim Arzt nötig und eine anschließende Analyse in einem mit dem Chip ausgerüsteten Labor. In Österreich ist die Versorgung ausgezeichnet, es gibt ausreichend Laboratorien, die diesen neuen Test machen. In anderen Ländern ist das nicht so - die Blutproben müssen daher meist bestens gesichert, aufwendig verpackt und gekühlt per Flugzeug zur Analyse gebracht werden. Das ist teuer und kompliziert. Nun hat ein Team der MedUni Wien rund um Studienleiter Prof. Dr. Rudolf Valenta vom Institut für Pathophysiologie und Allergieforschung nachgewiesen, dass der Multiallergentest mit getrocknetem Blut gleich gut funktioniert [1]. Dafür genügen wenige getrocknete Blutstropfen auf einen Streifen Whatman-Papier, dem weltweit am häufigsten verwendeten, extrem saugfähigen Blotting-Papier.

Die Inspiration zu dieser Entdeckung zogen die Wiener Forscher aus den Erfahrungen beim seit über 50 Jahren eingesetzten Neugeborenenscreening an der Universitätsklinik für Kinder- und Jugendheilkunde der MedUni Wien. Dabei wird den Neugeborenen mit einem Stich in die Ferse etwas Blut abgenommen, auf das Papier aufgetragen und die Babys damit auf angeborene Erkrankungen hin untersucht.

\section{Getrocknete Blutproben gleich} aussagekräftig wie frisches Serum Das zentrale Ergebnis: Die getrockneten, von einem Arzt abgenommenen, Blutproben zeigten das gleich Ergebnis wie eine Analyse von frischem Serum. Und das, egal wie lange die getrocknete Probe in einem Plastikumschlag beziehungsweise mittels Brief unterwegs war und bei welcher
Temperatur sie aufgetragen worden war. Prof. Dr. Victoria Garib: „Wir haben das bei Temperaturen von plus $37 \mathrm{Grad}$ ebenso gemessen wie bei minus 20 oder plus vier Grad. Das Ergebnis war immer dasselbe." Dabei wird aus dem Papier ein kleiner Teil herausgestanzt und in einem Plastikhütchen mit einer Flüssigkeit versetzt, danach werden die Antikörper in einer Zentrifuge herausgefiltert und auf den Allergie-Chip aufgetragen.

„Damit geben wir allen Ärzten und Ärztinnen weltweit die Möglichkeit, dass sie, auch wenn sie nur wenige Patienten mit Verdacht auf Allergien haben und kein Labor in der Nähe ist, einfach und schnell eine Analyse erhalten und damit den Betroffenen rasch helfen können“, ergänzt Valenta, der auch klarstellt: „Private Einsendungen von getrockneten Blutproben müssen die Labors natürlich ablehnen. Ein Arzt muss vorher feststellen, ob der Test überhaupt nötig ist und dann fachgerecht das Blut abnehmen und weiterschicken." Und zwar zum Preis einer normalen Briefsendung, also für einige wenige Euros.

Zum Vergleich: Das Versenden einer gekühlten, richtig gesicherten und verpackten Blutprobe per Air-Mail kostet zwischen 250 und 400 Euro. Gleichzeitig, so die Wiener Forscher, ist es möglich auch mit den getrockneten Blutproben beziehungsweise mit den daraus gewonnenen Antikörpern die Wirksamkeit von allergiebedingten Behandlungen mit Immuntherapie zu evaluieren und ein genaues Monitoring der Therapie durchzuführen.

\section{Über den Allergie-Chip}

Der Allergie-Chip, der an der MedUni Wien von der Arbeitsgruppe Valenta mitentwickelt wurde, deckt mit Hilfe von fluoreszenz-markierten Antikörpern mögliche Allergien auf - derzeit kann das Serum auf mehr als 100 Allergene gleichzeitig getestet werden, von Apfel bis Pollen, von Gräsern, Nahrungsmittelallergenen und Bienenstich bis hin zu diversen, eigentlich harmlosen Umweltstoffen wie Hausstaub. Vor allem bei Kindern ist die frühzeitige Allergie-Erkennung immens wichtig, um spätere chronische Erkrankungen wie etwa Asthma zu verhindern (• Abb. 1). Der Chip gilt mittlerweile als weltweit sicherste Methode zur Früherkennung von Allergien.

\section{Literatur \\ 1. Garib V, Rigler E, Gastager F, Campana R, Dorofeeva Y, Gattinger P, Zhernov Y, Khaitov $M$, Valenta $R$ (2019) Determination of IgE and IgG reactivity to more than 170 allergen molecules in paper dried blood spots, J Al- lergy Clin Immunol 143(1):437-440. https:// doi.org/10.1016/j.jaci.2018.08.047}

hautnah $2019 \cdot 18: 10$

https://doi.org/10.1007/s12326019-0314-z

(c) Springer-Verlag GmbH Austria, ein Teil von Springer Nature 2019 